\title{
PENERAPAN DISIPLIN POSITIF DALAM PENGASUHAN ANAK OLEH KELUARGA YANG TELAH DIREUNIFIKASI DI KOTA BANDUNG
}

\author{
Irniyati Samosir \\ Sekolah Tinggi Kesejahteraan Sosial Bandung \\ isamosir@yahoo.co.id
}

\begin{abstract}
The formulation of the problems in this research is to identify the model for positive discipline in child care within the reunited families in Bandung. The sub problems is to identify application of positive discipline in reunited families, to identify the result of positive discipline, to identify the reflection of positive discipline by the reunited families and to identify the improved model of positive discipline. The objectives of this research are to identify the child care pattern in reunified families and identify practices of positive discipline in reunified families in order to stregthen child care in the family. This research is using qualitative approach with action research methods. The data collection is collected using depth interview, documentation study, observation and discussions with child, parents and family. Data check was done with 1) Credibility test which covers: observation extension, increasing perseverance, triangulation, professional discussions and member check; 2) Transferability; 3) Dependability; 4) Conformability. For data analysis was done by qualitative data analysis, which covers these steps: data reduction, data display and drawing conclusions and verifications. The participants in this research are children and family which have been reunited, with the parent educational background up to elementary school, most of the parents is working as a laborer and household domestic worker and do not have the knowledge and skill on care. The result of this research has shown the increase knowledge for parents and reunited families on the necessity, the rights and methods of child care. These knowledge and understanding has an impact on the care pattern and parents and family attitude towards the child. The outcome of this research is a practical implication of positive discipline model in family based care for reunited families. In theory, this research confirms various assumption on positive discipline approaches especially on the role of giving warmth during care, and assumption on the child development phases from Erik Erikson which urgently needs to be understood by parents in order for them to give care appropriately with the child's development.
\end{abstract}

Key words: Positive Discipline; Reunified; Family Based Care

\begin{abstract}
Abstrak
Rumusan masalah penelitian ini adalah bagaimanakah model penerapan disiplin positif dalam pengasuhan anak oleh keluarga yang telah direunifikasi di kota Bandung. Sub-sub permasalahannya adalah bagaimana karakteristik dan interaksi anak dan keluarga yang telah direunifikasi, bagaimana perencanaan model disiplin positif untuk keluarga yang telah direunifikasi, bagaimana aplikasi disiplin positif oleh keluarga yang telah direunifikasi, bagaimana hasil yang dicapai dari penerapan disiplin positif, bagaiman refleksi terhadap penerapan disiplin positif oleh keluarga yang telah direunifikasi serta bagaimana penyempurnaan model penerapan disiplin positif. Adapun tujuan dari penelitian ini adalah ingin mengetahui bagaimana pola pengasuhan anak dalam keluarga yang telah direunifikasi serta bagaimana penerapan disiplin positif kepada keluarga yang telah direunifikasi dalam rangka memperkuat pengasuhan anak dalam keluarga. Penelitian ini menggunakan pendekatan kualitatif dengan metode penelitian action research. Pengumpulan data diperoleh menggunakan teknik wawancara mendalam, studi dokumentasi, observasi dan diskusi dengan anak,
\end{abstract}


orangtua dan keluarga. Sedangkan pemeriksaan data dilakukan dengan: 1) Uji kredibilitas yang meliputi : perpanjangan pengamatan, peningkatan ketekunan, triangulasi, diskusi teman sejawat dan membercheck, 2) Transferability; 3) Dependability; 4) Konfirmability. Untuk analisis data dilakukan melalui analisis data kualitatif, meliputi tahapan: reduksi data, display data, dan penarikan kesimpulan dan verifikasi. Partisipan dalam penelitian ini adalah anak dan keluarga yang telah direunifikasi, dengan latar belakang pendidikan orangtua tingkat SD, kebanyakan bekerja sebagai buruh dan pembantu rumah tangga serta tidak memiliki cukup pengetahuan dan keterampilan tentang pengasuhan. Hasil penelitian menunjukkan adanya penambahan pengetahuan orangtua dan keluarga yang telah direunifikasi mengenai kebutuhan, hak dan cara pengasuhan anak. Pengetahuan dan pemahaman tersebut berdampak kepada perubahan pada pola pengasuhan dan sikap orangtua dan keluarga terhadap anak. Penelitian ini juga menghasilkan implikasi praktis berupa Model Penerapan Disiplin Positif dalam Pengasuhan oleh Keluarga yang Telah Direunifikasi. Secara teoritik, penelitian juga mengkonfirmasi beberapa asumsi tentang pendekatan disiplin positif khususnya tentang peran pemberian kehangatan dalam pengasuhan, serta asumsi tentang tahapan perkembangan anak dari Erik Erikson yang sangat perlu dipahami oleh orangtua agar dapat memberikan pengasuhan sesuai kebutuhan perkembangan anak.

Kata kunci: Disiplin Positif; Reunifikasi; Pengasuhan Berbasis Keluarga

\section{Pendahuluan}

Persoalan kemiskinan menjadi isu dasar bagi dikirimkannya anak-anak ke panti asuhan. Isu tersebut bertumpang tindih dengan isu-isu lainnya seperti ketidak mampuan dan ketidak mauan orang tua dalam pengasuhan, isu proteksi dan kebutuhan pendidikan yang melatar belakangi tingginya jumlah anak di panti. Hasil penelitian Save The Children menunjukkan bahwa kebanyakan anak yang ditempatkan di panti karena alasan pendidikan dan bukan karena anak membutuhkan pengasuhan alternatif. Keluarga justru lebih memilih panti sebagai solusi dalam menyelesaikan permasalahan pengasuhan dan berbagai ketidakmampuan orang tua lainnya. Penelitian tersebut mencatat 128.016 orang anak ditempatkan pada 4.305 panti asuhan di 33 provinsi dan 395 kabupaten/kota. Jumlah ini berdasarkan data penerima bantuan subsidi Bahan Bakar Minyak (BBM) tahun 2007. (Save the Children, Unicef dan Depsos, 2007).

Pemisahan anak terjadi dalam dua cara: pemisahan secara kebetulan (accidental) dan pemisahan secara sengaja (deliberate). Kadang-kadang dua cara pemisahan yang berbeda ini juga disebut sebagai pemisahan tidak disengaja (involuntary) dan disengaja (voluntary). Namun, salah satu masalah yang timbul dari penyebutan pemisahan "voluntary" adalah bahwa pemisahan ini menyiratkan bahwa keluarga anak mempunyai pilihan. Meskipun pemisahan "voluntary" mungkin didasarkan pada keputusan yang tepat dan berdasarkan informasi yang diterima (informed decision) oleh keluarga, tetapi pemisahan ini biasanya disebabkan oleh kondisi buruk sehingga menimbulkan pertanyaan tentang seberapa banyak pilihan yang sesungguhnya ada dan opsi-opsi lain apa saja yang tersedia. (Sumber: UNICEF Indonesia - Modul Perlindungan Anak dalam Keadaan Darurat, 2008). Dalam konteks Indonesia, keterpisahan anak dengan keluarga lebih dikarenakan orangtua meninggalkan atau dengan sengaja menyerahkan anaknya ke dalam panti.

Isu ini menantang karena secara legal anak diakui sebagai pribadi yang memiliki hak yang sama dengan orang dewasa. Anak mempunyai hak untuk memiliki keluarga, sedangkan keluarga bertanggung jawab dalam memberikan pengasuhan kepada anggota keluarganya. Hal ini sesuai dengan apa yang terdapat dalam Undang-Undang Perlindungan Anak Nomor 35 Tahun 2014 pada pasal 14 yang menyatakan, "Setiap anak berhak untuk diasuh oleh orangtuanya sendiri, kecuali jika ada alasan/dan atau aturan hukum yang sah 
menunjukkan bahwa pemisahan itu adalah demi kepentingan terbaik bagi anak dan merupakan pertimbangan akhir". Pasal tersebut menegaskan bahwa, anak harus diasuh dan dibesarkan dalam suatu keluarga yang memiliki orang tua lengkap. Orangtua dan keluarga bertindak sebagai pengasuh utama yang menyediakan berbagai sarana dan dukungan bagi perkembangan anak. Keluarga berperan untuk membantu perkembangan kepribadian anak secara penuh, dalam suasana kebahagiaan dan rasa cinta dan pengertian. Tanggung jawab serta peran dari keluarga juga menyangkut pengasuhan, pemeliharaan dan melindungi anak, menumbuh kembangkan anak sesuai dengan kemampuan, bakat dan minatnya serta pencegahan terjadinya perkawinan pada usia anak-anak.

Pemisahan anak dari lingkungan asuhnya dapat menimbulkan tekanan akibat perubahan situasi hidup yang bersumber dari pengalaman hilangnya figur yang dekat dengan anak, situasi baru dan yang tidak dikenalinya, perubahan kebiasaan, terpisahnya anak dari "secure basenya." Selain itu, pengalaman perpisahan anak dengan pengasuhnya serta tingkat kematangan anak dalam memahami perpisahan dengan pengasuh utamanya menjadi salah satu faktor yang mempengaruhi anak untuk dapat beradaptasi dengan penempatannya di suatu lingkungan tertentu, termasuk panti asuhan. (Sumber : Hasil penelitian Karolina L Dalimunthe : Kajian mengenai kondisi psikososial anak yang dibesarkan di panti asuhan, Fakultas Psikologi Unpad, 2009).

Secara faktual, sebenarnya pemisahan anak dengan keluarga masih dapat dicegah jika keluarga mendapatkan dukungan yang memadai. Mengingat kemiskinan atau minimnya penghasilan menjadi alasan utama anak ditempatkan dalam pengasuhan alternatif dan mendorong pemisahan anak dari keluarganya. Kenyataannya kebanyakan orangtua ingin anaknya tetap bersama, tetapi takut untuk tidak mampu menjalankan tanggung jawabnya dalam perkembangan anak, umumnya dalam bidang pendidikan.
Sejalan dengan hal tersebut, pencegahan keterpisahan keluarga harus menjadi tujuan utama dalam penyelenggaraan pelayanan untuk anak-anak. Alternatif yang dapat diberikan adalah dukungan kepada keluarga. Hal ini merupakan pilihan pertama dan utama untuk mencegah pemisahan anak dari lingkungan keluarganya. Membantu keluarga rentan untuk mampu menjalankan perannya dalam pengasuhan anak. Memperkuat kapasitas orangtua dalam menghadapi masalah untuk mengurangi terjadinya perlakuan salah dan penelantaran anak. Membantu keluarga dan anak untuk mampu mempertahankan kebersamaannya, dengan demikian, dalam lingkup pengasuhan, pelayanan sosial kepada anak juga merupakan pelayanan yang bertujuan untuk memperkuat kapasitas orang tua dan keluarga untuk melaksanakan tanggung jawab orangtua terhadap anak-anak, serta mencegah terjadinya pemisahan anak dari keluarga. Hal yang dapat dilakukan juga adalah membangun kemampuan mengasuh anak (parenting education) untuk membantu orangtua dan keluarga memberikan pengasuhan yang baik serta melindungi anak.

Pengakuan bahwa negara mempunyai tanggung jawab untuk bertindak, jika keluarga karena suatu sebab tidak sanggup mengasuh anak mereka, diatur secara tegas dalam Undang-Undang Dasar (UUD) Republik Indonesia 1945. Pasal 34 ayat 1 UUD yang menyatakan bahwa "fakir miskin dan anakanak terlantar dipelihara oleh negara". Namun demikian, panti asuhan bagi anak yatim piatu dan anak terlantar sudah didirikan sebelum UUD 1945 dirumuskan dan diperkirakan bahwa konsep panti asuhan anak yang lebih formal yang berada di bawah pengawasan negara di Indonesia dikembangkan selama masa-masa penjajahan. (Pedoman Pelayanan Sosial Anak Terlantar di PSAA, Departemen Sosial (2002).

Penggunaan panti asuhan secara umum, merupakan salah satu bentuk dasar intervensi krisis personal, sosial atau ekonomi. Hal ini merupakan respon dari masyarakat luas melalui berbagai pendekatan khususnya 
pendekatan keagamaan untuk membantu masalah dalam masyarakat. Dengan kata lain, panti asuhan di Indonesia berkembang dengan peran menyediakan pelayanan sosial bagi anak-anak dan keluarga yang membutuhkan. Kuatnya unsur amal dalam pengelolaan panti asuhan, membuat para pengelola panti banyak yang tidak memahami bahwa panti asuhan merupakan alternatif terakhir dalam pengasuhan anak.

Dalam kaitannya dengan transformasi peran panti yang mengacu kepada pedoman internasional tentang pengasuhan tersebut dan aturan perundangan perlindungan anak di Indonesia, maka panti menjadi alternatif terakhir bagi penempatan anak yang membutuhkan layanan. Oleh karena itu, bila anak ditempatkan di panti padahal tidak membutuhkan pengasuhan alternatif maka perlu diupayakan tindakan reunifikasi anak dan keluarga khususnya bagi anak yang masih memiliki keluarga, baik keluarga inti ataupun keluarga besar anak. Reunifikasi yang dimaksud adalah penyatuan kembali antara anak yang berada di dalam panti dengan keluarganya yang tentunya dilakukan melalui melalui proses asesmen yang akurat baik terhadap anak maupun orang tua/keluarga. Akurasi dibutuhkan mengingat reunifikasi anak dan keluarga harus dilakukan dengan mempertimbangkan konsep keamanan anak, kesejahteraan dan permanensi, yakni solusi permanen bagi pengasuhan anak dalam keluarga.

Perencanaan permanensi adalah proses sitematis, dalam periode waktu yang singkat guna melaksanakan satu rangkaian kegiatan yang dirancang untuk membantu anak-anak hidup dalam keluarga yang menawarkan kesinambungan hubungan dengan orangtua atau pemberi asuhan yang merawat serta kesempatan untuk membangun hubungan seumur hidup. Konsep permanensi didasarkan pada nilai-nilai tertentu, termasuk keunggulan keluarga, pentingnya keluarga dan pentingnya ikatan kasih sayang orangtua dan anak. Keluarga dipandang penting karena menawarkan komitmen dan kontinuitas dimana setiap anggota keluarga mereka bertahan dalam tantangan hidup dengan keutuhan, berbagi masa depan bersama dimana nasib mereka saling terkait, keluarga memiliki status hukum dimana orangtua mempunyai hak dan tanggung jawab secara hukum untuk melindungi kepentingan dan kesejahteraan anak-anak. (Sumber: Maluccio, 1984 dalam Modul Perlindungan Anak dan Good Parenting).

Reunifikasi dan perencanaan permanensi bagi anak adalah memberikan kesempatan kepada anak-anak untuk membentuk kelekatan yang sehat, membantu pemenuhan kebutuhan anak untuk terikat kepada anggota keluarga yang menganggap mereka istimewa serta memiliki komitmen untuk menyediakan keselamatan, kesehatan dan kesejahteraan secara berkelanjutan. Perencanaan permanensi memandang bahwa setiap anak memiliki hak untuk tinggal di dalam rumah yang permanen dan stabil. Tujuannya adalah untuk membantu anak kembali ke rumah yang memberikan rasa aman dan nyaman bagi anak. Sejalan dengan konsep permanensi ini maka panti diharapkan dapat mendukung proses reunifikasi anak dengan keluarganya.

Pengasuhan dalam setiap keluarga tidak dapat digeneralisasikan, karena setiap keluarga memiliki karakteristik yang khas dan unik dalam pengasuhan. Pengasuhan dalam keluarga akan memberikan pengaruh kepada perkembangan anak, karena semua anggota keluarga secara alami mengalami proses tumbuh tanpa ada satupun tahapan hidup yang terlewati. Pengasuhan yang didapatkan anak ketika berada di dalam panti akan sangat berbeda dengan ketika anak berada dalam keluarga atau akan kembali kepada keluarga. Karenanya, keluarga-keluarga dalam masa transisi setelah reunifikasi seperti ini, baik anak maupun orangtua akan kembali mendapatkan tantangan penyesuaian diri dalam situasi baru yang kembali anak-anak temukan di dalam keluarga.

Pengasuhan merupakan pengalaman yang menyenangkan sekaligus dapat membuat frustrasi, menggembirakan, tetapi juga 
melelahkan. Kebanyakan keluarga mempelajari pengasuhan melalui tugas yang dilakukan sehari-harinya. Orangtua sangat sedikit mendapatkan informasi tentang perkembangan anak, sehingga seringkali hanya mengandalkan insting atau pengalaman masa kanak-kanaknya untuk mengasuh anak. Padahal pengasuhan bukan semata-mata perilaku instingtif. Menurut Maureen O'Loughlin \& Steve O'Loughlin, Glasgow (2008) dalam bukunya Social Work With Children and Family, dibutuhkan pemahaman mendasar tentang kapasitas orangtua dalam parenting yang mencakup: (gambar 1).

Salah satu pendekatan terkini dalam pengasuhan adalah positif disiplin yang mendasarkan pada dua konsep kunci yaitu struktur dan kehangatan. Struktur berkaitan dengan bagaimana orangtua merumuskan tujuan jangka panjang untuk pengasuhan anaknya, sedangkan kehangatan adalah bagaimana mengasuh anak dengan limpahan kasih sayang dan kelekatan (Joan Durrant, 2010). Positif disiplin bukanlah sebuah buku resep, tetapi suatu cara pikir yang mengarah kepada respon konstruktif yang memperhatikan perkembangan anak, pengasuhan yang efektif yang didalamnya terdapat aspek pengaturan emosi dan efikasi diri (self efficacy), serta memperhatikan hakhak anak. Oleh karena itu, pengasuhan dengan penerapan disiplin positif bukanlah pengasuhan yang mengandalkan kekerasan. Kebanyakan orangtua berfikir bahwa disiplin identik dengan omelan dan pukulan, sehingga orangtua seringkali menggunakannya atas nama disiplin.

Berbeda dengan anggapan tersebut, positif disiplin merupakan pendekatan dengan seperangkat prinsip yang berfungsi untuk mengajar, memberikan informasi serta menyediakan dasar bagi orangtua dalam mengasuh dan membantu pertumbuhan anakanak. Positif disiplin mengupayakan bagaimana membantu orangtua untuk mengasuh anaknya secara optimal termasuk dalam penerapan disiplin.

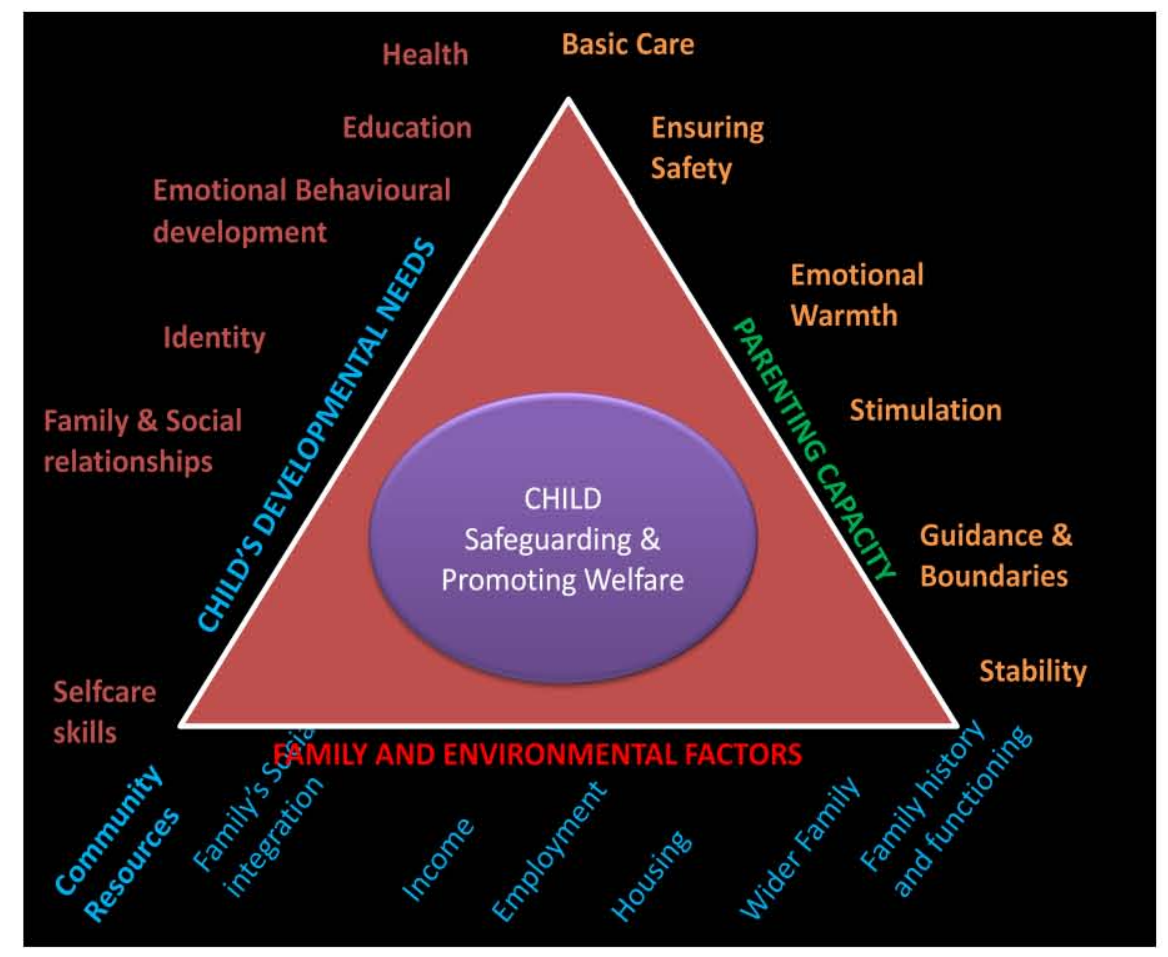

Gambar 1

Pemahaman Dasar Kapasitas Orangtua dalam Parenting 
Mempertimbangkan aspek positif dari pendekatan ini, penulis berpandangan bahwa pendekatan ini perlu diterapkan pada anak dan keluarga di Kota Bandung yang mengalami keterpisahan dan telah berhasil direunifikasi. Hal ini perlu dilakukan untuk membantu para orangtua atau keluarga dalam memberikan pengasuhan yang terbaik terhadap anakanaknya.

\section{Tujuan}

Tujuan penelitian adalah ingin mengetahui bagaimana pola pengasuhan anak dalam keluarga yang telah direunifikasi serta bagaimana penerapan disiplin positif kepada keluarga yang telah direunifikasi dalam rangka memperkuat pengasuhan anak dalam keluarga.

\section{Metode}

Penelitian ini menggunakan metode kualitatif. Metode kualitatif dipilih mengingat permasalahan yang diteliti bertujuan untuk menggali permasalahan secara mendalam, dengan demikian dapat menemukan suatu pola yang dapat digunakan dalam menyusun suatu model pendekatan yang bersifat komprehensif dalam penyelesaian masalah yang dihadapi.

Disain penelitian yang digunakan adalah penelitian tindakan atau action research. Penelitian tindakan merupakan upaya mengujicobakan ide-ide ke dalam praktik untuk memperbaiki atau mengubah sesuatu agar memperoleh dampak nyata dari situasi (Kemmis;1983 dalam Nurul Zuriah:2006). Berdasarkan tujuan dari penelitian tindakan tersebut, maka tujuan utama yang ingin dicapai adalah membawa perubahan bagi orangtua dan anak juga pengasuh dalam kaitannya dengan pola pengasuhan anak. Adapun bentuk perubahan yang diharapkan melalui penelitian ini meliputi: perubahan pengetahuan dan perilaku dari orangtua terkait dengan penerapan disiplin positif dalam pengasuhan anak oleh keluarga yang telah direunifikasi.
Analisis data yang digunakan adalah tehnik analisis data kualitatif. Teknik analisa data dalam penelitian ini dilakukan secara interaktif melalui proses: reduksi data, penyajian data, penarikan kesimpulan dan verifikasi.

Penelitian ini dilakukan terhadap empat keluarga yang sebelumnya telah berhasil direunifikasi dari dua panti yang berada di kota Bandung. Lokasi ke empat keluarga tersebut terletak di wilayah Kabupaten/Kota Bandung, yakni daerah Munjul Bale Endah, Awiligar Bandung, Kopo dan Ujung Berung Bandung.

\section{Hasil dan Pembahasan}

Penerapan disiplin positif merupakan suatu pendekatan yang masih baru dalam pengasuhan, khususnya kepada keluargakeluarga yang memiliki karakteristik menantang, baik dari segi latar belakang pendidikan orangtua yang mayoritas lulusan $\mathrm{SD}$, pekerjaan dan situasi ekonomi keluarga yang tidak menentu, kurangnya pengetahuan dan pemahaman orangtua terhadap hak dan kebutuhan serta tahap-tahap perkembangan anak. Gambaran situasi tersebut merupakan beberapa faktor yang menggambarkan kompleksitas masalah yang dihadapi orangtua dan keluarga yang melatarbelakangi penempatan anak di dalam panti.

Kompleksitas situasi yang dihadapi anak-anak di dalam panti seperti piket, sekolah, les tambahan yang sudah menjadi aktivitas rutin setiap hari mulai dari bangun pagi hingga istirahat di malam hari, kemarahan terhadap keluarga akibat keterpisahan, mendapat perlakuan salah dari pengurus panti, ketidak mampuan serta konflik dalam keluarga, sarana dan prasarana yang berbeda dengan apa yang mereka dapatkan dalam rumah atau keluarga dimana semua hal tersebut menjadi suatu pertimbangan ketika anak akan direunifikasi.

Reunifikasi anak yang telah dilakukan sebelumnya adalah hasil kerjasama dengan lembaga Save The Children melalui Pusat Dukungan Anak dan Keluarga (PDAK) bersinergi dengan Forum Komunikasi Panti 
Sosial (FKPS) Bandung serta Kantor Dinas Sosial Kota Bandung dan Dinas Sosiap Propinsi Jawa Barat. Pusat dukungan anak dan keluarga (PDAK) merupakan salah satu program yang diberikan untuk mendukung reunifikasi antara anak dan keluarga.

Dukungan yang diberikan berupa dukungan sosial, psikososial, pemberdayaan keluarga dan juga pelatihan pengasuhan bagi orangtua didasarkan pada asesmen dan penggalian kebutuhan keluarga. Dukungan lainnya juga merupakan bantuan dalam menghubungkan keluarga dengan sistem sumber yang tersedia.

Adapun karakteristik anak dan keluarga yang menjadi sasaran program ini adalah: 1) Anak yang berada di dalam panti asuhan dan yang masih memiliki orangtua dan atau keluarga, 2) Anak dan keluarga yang kurang mampu secara ekonomi juga dalam pengasuhan, 3) Anak yang terpaksa bekerja dijalanan dan tereksploitasi.

Mayoritas kondisi ekonomi keluarga dampingan PDAK merupakan keluarga dengan latar belakang ekonomi rendah, pekerjaan yang tidak tetap dan rata-rata sebagai buruh bangunan, buruh tani dan pengangguran menjadikan kondisi perekonomian keluarga semakin terpuruk. Aspek-aspek tersebut merupakan salah satu faktor pendorong bagi keputusan orangtua menempatkan anak di dalam panti. Secara pendidikan, orangtua anak rata-rata tamatan dari SD dan SMP.

Berdasarkan hasil pendataan saat penelitian, terdapat 46 anak yang sedang mendapatkan pendampingan dari Pusat Dukungan Anak dan Keluarga (PDAK) bekerjasama dengan Dinas Sosial Propinsi Jawa Barat dan Dinas Sosial Kota Bandung melalui Forum Komunikasi Panti Sosial Bandung. Dari 46 anak tersebut, sebanyak 25 anak telah berhasil direunifikasi dan 21 anak akan segera direunifikasi dengan keluarganya. Sebanyak 21 anak berjenis kelamin laki-laki dan 25 anak berjenis kelamin perempuan. Dari 46 anak yang mendapatkan pendampingan dari PDAK, sebanyak empat anak bersama orangtuanya menjadi patisipan dalam penelitian ini dengan mempertimbangkan keterwakilan menurut tahap perkembangan dan serta keterwakilan gender yang berbeda dari masing-masing partisipan.

Tabel 1

Karakteristik Partisipan

\begin{tabular}{c|c|c|c|c|c|c|c|c}
\hline No & $\begin{array}{c}\text { Inisial } \\
\text { Anak }\end{array}$ & $\begin{array}{c}\text { Umur } \\
\text { (Tahun) }\end{array}$ & $\begin{array}{c}\text { Jenis } \\
\text { Kelamin } \\
(\mathrm{L} / \mathrm{P})\end{array}$ & Pendidikan & $\begin{array}{c}\text { Inisial } \\
\text { Orangtua }\end{array}$ & $\begin{array}{c}\text { Pendidikan } \\
\text { Orangtua }\end{array}$ & $\begin{array}{c}\text { Pekerjaan } \\
\text { Orangtua }\end{array}$ & $\begin{array}{c}\text { Terpisah } \\
\text { (Tahun) }\end{array}$ \\
\hline 1 & NL & 9 & $\mathrm{P}$ & SD kelas 3 & AA/UN & SD & PRT & 4 \\
\hline 2 & RZ & 3 & $\mathrm{~L}$ & $\begin{array}{c}\text { Belum } \\
\text { Sekolah }\end{array}$ & SBR/AH & SD & Buruh & 3 \\
\hline 3 & IW & 12 & $\mathrm{~L}$ & SMP kelas 1 & MS/SMan & SD & Buruh & 6 \\
\hline 4 & RA & 16 & P & SMA kelas 2 & SA/TS & SMP & $\begin{array}{c}\text { Buruh } \\
\text { Pabrik }\end{array}$ \\
\hline
\end{tabular}

Sumber: Hasil Penelitian Tahun 2012 


\section{Interaksi Anak dengan Keluarga}

Konteks Komunikasi yang dimaksud adalah merupakan seluruh proses yang diperlukan untuk memahami pikiran-pikiran yang dimaksud oleh orang lain. Berdasarkan penelitian yang dilakukan, gambaran secara umum komunikasi yang terjalin diantara anggota keluarga yang telah direunifikasi terlihat biasa saja. Berdasarkan beberapa gambaran komunikasi yang dilakukan, anak lebih sering berbagi cerita, berkomunikasi dan terbuka dengan peer groupnya di luar rumah dibandingkan dengan keluarga inti di dalam rumah. Sementara pada beberapa keluarga, komunikasi diartikan hanya sekedar bercerita mengeluhkan kondisi ekonomi keluarga dengan anggota keluarga yang sudah lebih dewasa untuk dapat berpikir bersama serta dapat membantu orangtua memenuhinya.

Berdasarkan penelitian yang dilakukan, dapat diketahui adanya perbedaan antara aktifitas anak-anak ketika masih di dalam panti dengan saat tinggal bersama keluarga. Aktifitas anak ketika berada di dalam panti telah terjadwal dan hampir tidak memiliki waktu luang untuk bermain di luar panti. Gambaran secara umum kegiatan anak di dalam panti diawali dengan bangun pagi pada pukul 04.00 wib. Setelah menunaikan ibadah pagi hari kemudian melaksanakan piket rutin yang sudah menjadi tugas dan tanggung jawab mereka. Sepulang sekolah dan setelah makan siang, anak diwajibkan tidur siang. Sore hari kembali mengerjakan piket rutin masing-masing dan mengikuti les tambahan. Sedangkan di malam hari setelah makan malam anak wajib mengikuti belajar bersama sebelum kemudian tidur malam. Sedangkan gambaran aktivitas anak dalam rumah setelah direunifikasi adalah sekolah, bermain dan membantu orangtua. Gambaran aktivitas sehari-hari anak ketika dalam panti maupun setelah reunifikasi, berdasarkan pembuatan daily schedule saat penelitian adalah sebagai berikut:

Tabel 2

Aktivitas Rutin Anak dalam Panti

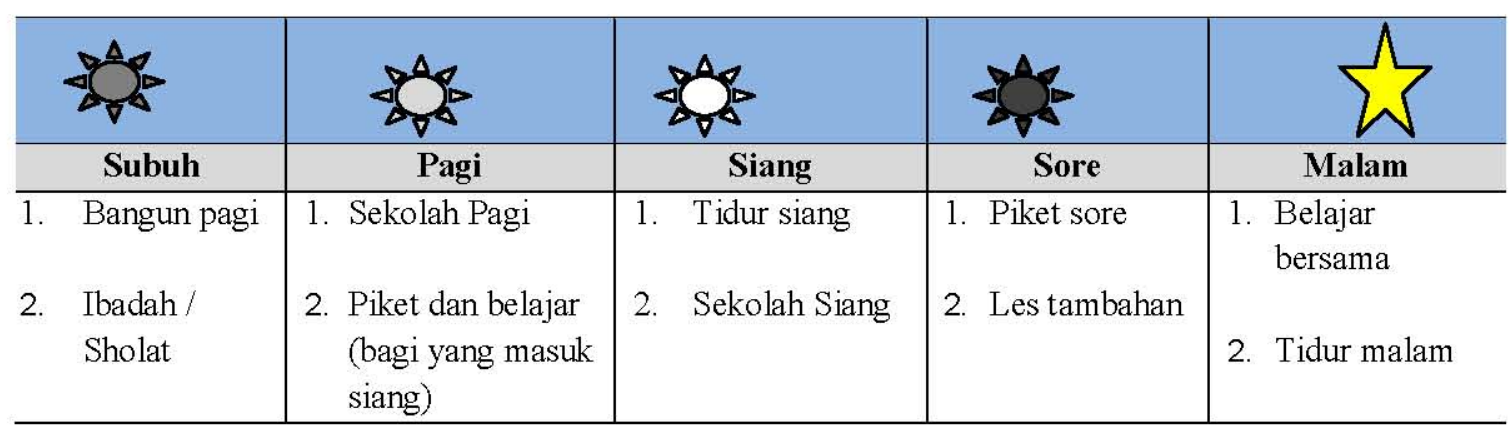

Tabel 3

Aktivitas Rutin Anak dalam Rumah Setelah Reunifikasi

\begin{tabular}{l|l|l|l|l}
\hline & Subuh & Pagi & Siang & Sore \\
\hline $\begin{array}{l}\text { 1. Bangun pagi } \\
\text { Ibadah/ } \\
\text { Sholat }\end{array}$ & 1. Sekolah Pagi & $\begin{array}{l}\text { 1. Sekolah Siang } \\
\text { 1. Bermain }\end{array}$ & $\begin{array}{l}\text { 1. Belajar } \\
\text { 2. Membantu } \\
\text { orangtua }\end{array}$ & 2. Tidur malam \\
\hline
\end{tabular}


Interaksi dalam keluarga juga dapat dilihat atau berkaitan dengan bagaimana masingmasing anggota keluarga dapat mengemukakan pendapat dan keinginan mereka satu dengan lainnya serta mendapat respon dari keluarga. Mengingat bahwa komunikasi disebut efektif apabila ide, gagasan dan lain-lain dapat ditangkap sesuai keinginan pengirim pesan yang kemudian ditanggapi dengan baik oleh penerima. Interaksi dan komunikasi yang terjadi dalam keluarga informan pada umumnya menunjukkan komunikasi yang terjadi berada dalam tahap interaksi bidang kepribadian yang umum (public areas) dimana individuindividu didalamnya berusaha untuk menghindari konflik, sedikit mengevaluasi diri serta menyesuaikan hubungan dengan norma sosial pada situasi tersebut. Maka komunikasi yang terjadi belum sampai pada tahap hubungan stabil (stable exchange stage) dimana pola komunikasi mengarah kepada keterbukaan umum, pribadi dalam semua tingkat baik yang bersifat umum dan pribadi. Komunikasi verbal dan non verbal yang berorientasi kepada lingkungan serta mulai memiliki tahap emosi yang efektif terhadap lawan bicara.

Unsur lain yang dipandang perlu oleh peneliti untuk dapat melihat bagaimana bentuk interaksi anak dan keluarga yang telah berhasil direunifikasi ini adalah dari segi pemberian arahan atau pemberian perintah maupun tugas yang jelas kepada anggota keluarganya. Dengan demikian akan tergambar apakah interaksi yang terjadi bersifat dua atau satu arah saja, interaksi yang hangat atau dingin, maupun interaksi yang kaku atau fleksibel. Arahan dari orangtua yang dimaksud adalah berupa pemberian aturan-aturan yang jelas dalam keluarga serta batasan yang berlaku dalam keluarga. Sedangkan untuk pemberian atau pembagian tugas yang jelas dalam keseharian keluarga, rata-rata keluarga mengakui tidak memiliki jadwal rutin yang disepakati bersama.
Tidak seperti yang diterapkan di dalam panti dimana anak sebelumnya tinggal dengan tugas dan tanggung jawab serta sanksi yang sudah jelas bagi setiap penghuni panti. Dalam keluarga, pembagian tugas tersebut dipandang tidak begitu penting dan diharapkan anggota keluarga memiliki kesadaran untuk melakukan tanggung jawabnya.

Mengingat peranan keluarga sebagai pembagi kehidupan individu ke dalam tingkat-tingkat peralihan usia dalam rangka pembentukan watak dan perilaku anggota keluarga agar terinternalisasi kedalam keseluruhan nilai budaya yang menjadi panutan masyarakatnya dalam bersosialisasi, keluarga diharapkan mampu memberikan arahan dan petunjuk yang jelas dalam berperilaku. Keluarga merupakan lingkungan pertama dimana anak mulai mengadakan persepsi, baik mengenai hal-hal yang berada di luar dirinya, maupun mengenai dirinya sendiri.

\section{Perencanaan Model Penerapan Positif Disiplin dalam Keluarga yang Telah Direunifikasi}

Perencanaan model intervensi diperlukan untuk mencapai tujuan yang diharapkan dengan menggunakan tahap-tahap kegiatan yang telah dipersiapkan sebelumnya. Kegiatan perencanaan dilakukan dengan melibatkan partisipan yang berjumlah empat keluarga yang telah direunifikasi. Partisipan telah memberikan informasi dan gambaran umum mengenai situasi pengasuhan dalam keluarga. Penyusunan rencana lebih rinci untuk masingmasing kegiatan digambarkan dalam tabel 4 berikut: 
Tabel 4

Rencana Penerapan Positif Disiplin

pada Keluarga yang Telah Direunifikasi di Kota Bandung

\begin{tabular}{|c|c|c|c|c|}
\hline NO & $\begin{array}{l}\text { NAMA PROGRAM, JENIS KEGIATAN } \\
\text { DAN TUJUAN YANG INGIN DICAPAI }\end{array}$ & LANGKAH-LANGKAH & $\begin{array}{l}\text { SISTEM SUMBER DAN } \\
\text { PENANGGUNG JAWAB KEGIATAN }\end{array}$ & SASARAN \\
\hline \multicolumn{5}{|c|}{$\begin{array}{l}\text { Penerapan Positif Disiplin (Peningkatan kemampuan, pemahaman, memperkuat pengasuhan dan partisipasi pengembalian fungsi dan peran orangtua dan keluarga dalam } \\
\text { pengasuhan) }\end{array}$} \\
\hline \multirow[b]{2}{*}{1.} & \multicolumn{4}{|l|}{ Identifikasi Situasi-Situasi Pengasuhan } \\
\hline & $\begin{array}{l}\text { Memahami dan mengenali situasi sehari-hari yang } \\
\text { dihadapi orangtua dan keluarga dalam rumah. } \\
\text { Mampu mengatasi situasi-situasi terebut }\end{array}$ & $\begin{array}{l}\text { Mengajak orangtua berdiskusi mengenai } \\
\text { tahap-tahap perkembangan anak } \\
>\text { Mengajak orangtua berdiskusi tentang situasi } \\
\text { rumah dan pengasuhan yang diberikan } \\
\text { setiap hari }\end{array}$ & $\begin{array}{l}\text { Dalam kegiatan ini orangtua dan keluarga } \\
\text { yang telah direunifikasi merupakan sistem } \\
\text { sumber sekaligus pelaksana kegiatan, } \\
\text { dengan didampingi oleh peneliti }\end{array}$ & $\begin{array}{l}>\text { Orangtua } \\
>\text { Anak }\end{array}$ \\
\hline \multirow[b]{2}{*}{2.} & \multicolumn{4}{|c|}{ Identifikasi Tujuan Jangka Panjang Pengasuhan } \\
\hline & $\begin{array}{l}\text { Merencanakan pengasuhan yang baik dan tepat } \\
\text { bagi anak. } \\
>\text { Membantu orangtua dan keluarga mengelola } \\
\text { sikap dan tindakan dalampengasuhan }\end{array}$ & $\begin{array}{l}\text { Mengajak orangtua berdiskusi mengenai } \\
\text { tujuan jangka panjang pengasuhan } \\
>\text { Membuat daftar situasi sehari-hari yang } \\
\text { dihadapi, solusi yang diberikan serta tujuan } \\
\text { antara. } \\
\text { Mengajak orangtua untuk membayangkan } \\
\text { keadaan anak setelah 5- } 18 \text { tahun ke dapan. }\end{array}$ & $\begin{array}{l}>\text { orangtua dan keluarga yang telah } \\
\text { direunifikasi } \\
>\text { Peneliti }\end{array}$ & $\begin{array}{l}>\text { Orangtua } \\
>\text { Anak }\end{array}$ \\
\hline \multirow[b]{2}{*}{3.} & \multicolumn{4}{|c|}{ Identifikasi Struktur dan Kehangatan dalam Keluarga } \\
\hline & $\begin{array}{l}\text { Mengenali dan memahami gambaran interaksi } \\
\text { dan komunikasi dalam keluarga } \\
\text { Meningkatkan pengetahuan serta pemahaman } \\
\text { orangtua dan keluarga tentang attachment } \\
\text { dalam keluarga } \\
>\text { Menyediakan arahan dan dan aturan yang jelas } \\
\text { dalam pengasuhan keluarga }\end{array}$ & $\begin{array}{l}\text { Berdiskusi dengan orangtua dan keluarga } \\
\text { mengenai pemanfaatan waktu luang dalam } \\
\text { keluarga } \\
>\text { Berdiskusi mengenai bentuk interaksi dan } \\
\text { komunikasi dalam keluarga } \\
>\text { Berdiskusi mengenai ungkapan rasa } \\
\text { sayang,perhatian terhadap anggota keluarga } \\
>\text { Pembagian peran dalam keluarga } \\
>\text { Aturan-aturan yang berlaku dalam keluarga } \\
\end{array}$ & $\begin{array}{l}>\text { orangtua dan keluarga yang telah } \\
\text { direunifikasi } \\
>\text { Peneliti }\end{array}$ & $\begin{array}{l}>\text { Orangtua } \\
>\text { Anak }\end{array}$ \\
\hline & \multicolumn{4}{|c|}{ Identifikasi Penyelesaian Masalah Pengasuhan dalam Keluarga } \\
\hline 4. & $\begin{array}{l}\text { Meningkatkan pemahaman orangtua dan } \\
\text { keluarga tentang tahap-tahap perkembangan } \\
\text { anak } \\
>\text { Orangtua dapat memahami situasi anak } \\
\text { berdasarkan tahapan perkembangannya } \\
>\text { Membantu orangtua memahami dan } \\
\text { memandang anak dari perspektif anak }\end{array}$ & $\begin{array}{l}\text { Berdiskusi dengan orangtua dan anak } \\
\text { mengenai masalah-masalah yang sering } \\
\text { dihadapi dalam pengasuhan di dalam rumah } \\
\text { Mengunkapkan harapan dan keinginan } \\
\text { masing-masing (orangtua terhadap anak, } \\
\text { dan anak kepada orangtua) }\end{array}$ & $\begin{array}{l}>\text { orangtua dan keluarga yang telah } \\
\text { direunifikasi } \\
>\text { Peneliti }\end{array}$ & $\begin{array}{l}>\text { Orangtua } \\
>\text { Anak }\end{array}$ \\
\hline
\end{tabular}




\section{Aplikasi Disiplin Positif dalam Keluarga yang Telah Direunifikasi}

Gambaran ringkas dari ke empat keluarga sangat bervariasi. Dari segi ekonomi penghasilan setiap harinya rata-rata sekitar Rp. 30.000 (tiga puluh ribu rupiah) dengan pekerjaan sebagai karyawan pabrik, pembantu rumah tangga, buruh bangunan dan petugas kebersihan keliling di lingkungan tempat tinggalnya. Struktur keluarga single parent akibat adanya perceraian dalam keluarga menjadikan masing-masing keluarga ini menjadi unik dan menarik. Jumlah angota keluarga yang relatif banyak juga menjadi salah satu faktor yang turut memberikan warna dalam keluarga masing-masing.

Semua kondisi dan situasi ini menjadikan kasus dalam penelitian ini menjadi unik. Hal ini dapat dilihat dari matriks situasi pengasuhan anak dalam keluarga yang telah direunifikasi (Tabel 5).

Situasi-situasi ini menjadi salah satu tantangan sekaligus peluang bagi penerapan disiplin positif. Menantang ketika diperhadapkan dengan latar belakang keluarga secara umum. Tingkat pendidikan orangtua yang rendah, pekerjaan orangtua tidak tetap, kondisi ekonomi keluarga yang tidak mencukupi, keterpisahan dengan anak selama bertahuntahun, orangtua yang menjadi single parent. Sementara positif disiplin merupakan salah satu bentuk pendekatan pengasuhan yang menuntut tingkat pemahaman serta kemampuan orangtua dalam merencanakan pengasuhan jangka panjang.

Menjadi peluang bagi penerapan positif disiplin dimana reunifikasi dilakukan. Orangtua dan keluarga memiliki niat dan kemauan untuk kembali memberikan perhatian, kasih sayang yang selama bertahuntahun kedekatan diantara orangtua dan anak tidak dirasakan. Besarnya keinginan anak untuk kembali ke rumah dan tinggal bersama orangtua dan keluarga mereka. Karena positif disiplin adalah seperangkat prinsip yang menyediakan dasar bagi orangtua yang berfokus kepada prinsip penghargaan dan perkembangan anak.

Mengingat bahwa pengasuhan terjadi dalam konteks multi-dimensi dimana faktor makro mempengaruhi faktor mikro dan juga sebaliknya. Dengan demikian untuk mengoptimalkan tingkat mikro yakni kesejahteraan anak dan pengasuhan dapat dicapai secara efektif jika kita mempertimbangkan semua tingkat sistem ekologi keluarga serta perkembangan anak dan keluarga.

Hal lain yang diperoleh dalam penelitian ini adalah beberapa faktor pendorong mengapa orangtua memilih panti sebagai solusi utama dalam membantu mereka memecahkan permasalahan yang mereka hadapi, yakni persoalan ekonomi. Selain ketidak mampuan dalam pengasuhan, kurangnya pemahaman keluarga terhadap hak-hak anak juga merupakan salah satu alasan mengapa para keluarga begitu mudahnya mengambil keputusan serta memasukkan anak-anak mereka ke dalam panti.

Keterpisahan yang menahun antara anak dan keluarga telah memberikan dampak kepada perkembangan anak secara keseluruhan. Lingkungan baru (panti) yang terkadang secara fisik jauh lebih baik bangunannya dari keadaan di rumah sendiri, serta fasilitasfaslitas yang diperoleh jauh lebih memadai dibandingkan di rumah sendiri, teman baru yang diperolehnya didalam panti dapat memberikan dampak untuk malas kembali ke rumah atau kepada keluarga. Sehingga ketika mereka akan direunifikasi kepada keluarga, baik anak dan keluarga perlu dipersiapkan terlebih dahulu untuk menghadapi situasisituasi baru yang akan mereka hadapi, khususnya dalam pengasuhan. Penerapan positif disiplin melalui pelatihan good parenting menjadi salah satu pendekatan dan teknik yang dapat diterapkan kepada anak dan keluarga yang telah ataupun yang akan direunifikasi tersebut. 
Tabel 5

Matriks Situasi Pengasuhan Anak dalam Keluarga Informan

\begin{tabular}{|c|c|c|c|c|c|c|c|c|c|c|}
\hline \multirow{2}{*}{ NO } & \multirow{2}{*}{ KELUARGA } & \multirow{2}{*}{$\begin{array}{c}\text { JUMLAH } \\
\text { ANGGOTA } \\
\text { KELUARGA }\end{array}$} & \multirow{2}{*}{$\begin{array}{c}\text { SITUASI } \\
\text { PENGASUHAN } \\
\text { ANAK }\end{array}$} & \multicolumn{2}{|c|}{$\begin{array}{l}\text { KEPEMILIKAN } \\
\text { RUMAH }\end{array}$} & \multirow{2}{*}{$\begin{array}{l}\text { PEKERJAAN } \\
\text { ORANGTUA }\end{array}$} & \multicolumn{2}{|c|}{$\begin{array}{c}\text { STATUS } \\
\text { PERKAWINAN }\end{array}$} & \multicolumn{2}{|c|}{$\begin{array}{c}\text { PENDIDIKAN } \\
\text { ORANGTUA }\end{array}$} \\
\hline & & & & Pribadi & Ngontrak & & Utuh & $\begin{array}{l}\text { Single } \\
\text { Parent }\end{array}$ & $\mathrm{SD}$ & SMP \\
\hline 1 & SBR dan $\mathrm{AH}$ & 8 orang & 6 anak belum mandiri & & & $\begin{array}{l}\text { Buruh bangunan, Petugas } \\
\text { kebersihan lingkungan/ IRT }\end{array}$ & & & & \\
\hline 2 & UN & 3 orang & $\begin{array}{c}\text { Anak pertama DO dan } \\
\text { tinggal di jalan, anak } \\
\text { bungsu lemah fisik }\end{array}$ & & & PR T & & & & \\
\hline 3 & MS & 4 orang & IW suka malas ke sekolah & & & $\begin{array}{l}\text { Buruh bangunan, nyabit } \\
\text { rumput dan membuat arang }\end{array}$ & & & & \\
\hline 4 & SA dan TS & 3 orang & $\begin{array}{c}\text { Anak bungsu di Jawa, TS } \\
\text { adalah ibu tiri bagi RA }\end{array}$ & & & Buruh pabrik & & & & \\
\hline
\end{tabular}

Keterangan :

2 Keluarga memiliki rumah pribadi

2 Keluarga memiliki rumah kontrakan

2 Keluarga memiliki status perkawinan yang utuh
2 Keluarga memiliki status single parent

3 Keluarga tamatan SD

1 keluarga tamatan SMP 
Tercipta dan tersedianya pengasuhan yang baik, kehangatan dalam keluarga diharapkan akan dapat menjamin anak yang telah direunifikasi tetap tinggal dan betah di rumah dan tidak kembali lagi ke dalam panti, sehingga adanya kemungkinan pola perlakuan yang berulang (siklus) yang nantinya dapat menjadi pembelajaran yang akan diadaptasi oleh anak ketika mereka beranjak dewasa dan membentuk suatu keluarga baru dapat dikurangi bahkan diputus mata rantainya.

Berikut adalah siklus yang terjadi secara umum dimana beberapa orangtua dan keluarga menitipkan anak mereka ke panti-panti asuhan:

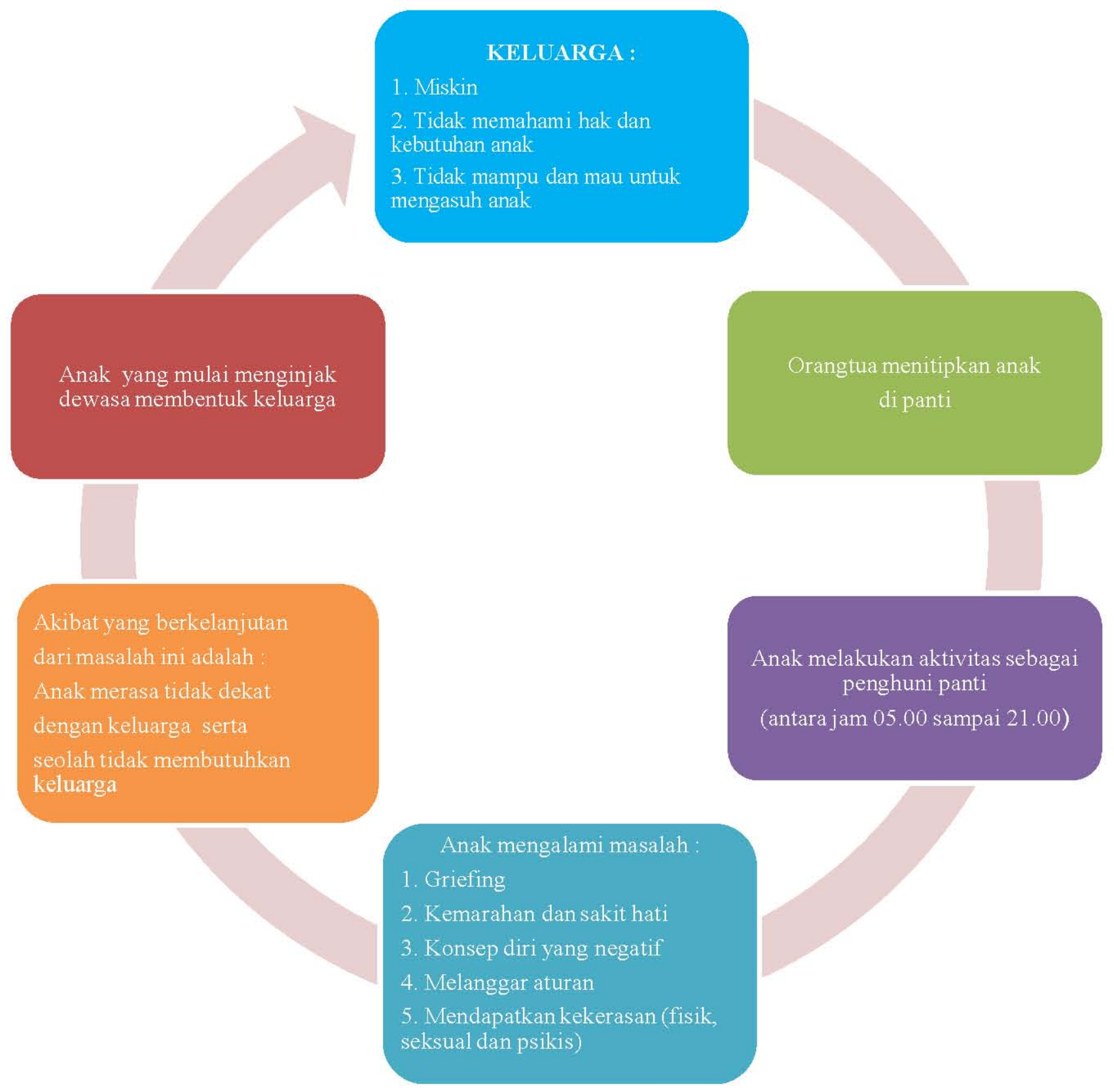

Gambar 2

Siklus Orangtua/Keluarga dalam Menitipkan Anak ke Panti Asuhan 
Penyempurnaan model intervensi yang dilaksanakan berdasarkan asumsi yang menunjukkan bahwa keluarga merupakan tempat terbaik bagi tumbuh kembang anak. Orangtua dan keluarga memiliki niat dan keinginan untuk dapat tetap mengasuh dan tinggal bersama anggota keluarga mereka. Hal ini merupakan modal untuk pelaksanaan intervensi penerapan disiplin positif bagi orangtua dan keluarga. Penyempurnaan model intervensi yang telah dilaksanakan tersebut digambarkan dalam bagan berikut ini (gambar $3)$.

Keterpisahan dan penempatan anak di dalam panti lebih didasarkan kepada faktor ekonomi yang tidak memadai, sehingga orangtua dan keluarga tidak mampu menyekolahkan anak. Dengan kata lain penggunaan panti asuhan sebagai bentuk dasar intervensi krisis personal, sosial, atau ekonomi. Mayoritas anak-anak di panti asuhan masih memiliki salah satu, atau jika tidak kedua orangtuanya masih hidup. Hal ini juga menunjukkan bahwa banyak keluarga menempatkan anak-anak di panti asuhan dalam rangka menjamin akses pada pendidikan. Oleh karena itu, sebagian besar penempatan anak di panti asuhan sesungguhnya masih dapat dihindari, jika penekanannya lebih ditempatkan pada penyediaan dukungan ekonomi dan sosial kepada keluarga-keluarga rentan yang tidak memungkinkan mereka mengasuh dan menjamin akses pendidikan untuk anak-anak mereka.

Peningkatan jumlah anak-anak yang berada di luar asuhan orangtua dan penggunaan panti asuhan sebagai cara yang digunakan untuk menghadapi keadaan sebagaimana disebutkan diatas perlu mendapatkan perhatian. Perencanaan permanensi dan reunifikasi merupakan salah satu pendekatan yang tepat dalam membantu permasalahan anak yang tinggal di dalam panti, terutama bagi anakanak yang hidup tanpa asuhan orangtua. Indonesia telah mengakui tanggung jawab utama keluarga dan orangtua, yaitu untuk merawat dan melindungi anak-anak mereka dan kita tahu bahwa jutaan anak yang tidak dirawat oleh orangtua mereka, dengan berbagai alasan, dirawat oleh saudara mereka dan bukan di dalam panti. Ini buktinya, bahwa sebenarnya keluarga memiliki peluang yang sangat besar dalam membantu penyelesaian masalah anak dan keluarga.

Berbagai bantuan dan dukungan dari semua pihak seharusnya diberikan langsung kepada keluarga, sehingga keluarga tetap dapat merawat anak-anak secara benar dan layak. Pengasuhan dalam keluarga merupakan pilihan yang tepat dan disukai oleh anak dan juga menjadi tempat utama yang diinginkan oleh semua. Sehubungan dengan hal tersebut, penelitian ini menjadi salah satu bentuk dukungan yang diberikan kepada orangtua dan keluarga untuk membantu mempersiapkan pengasuhan dalam keluarga, membantu mengatasi kesulitan dan memperkenankan anak-anak untuk tumbuh di bawah asuhan dan perlindungan keluarga, serta mendukung keluarga dalam berbagai cara yang dapat memungkinkan anak-anak tinggal dengan keluarga atau kerabatnya, dimana salah satunya adalah dengan penerapan disiplin positif. 


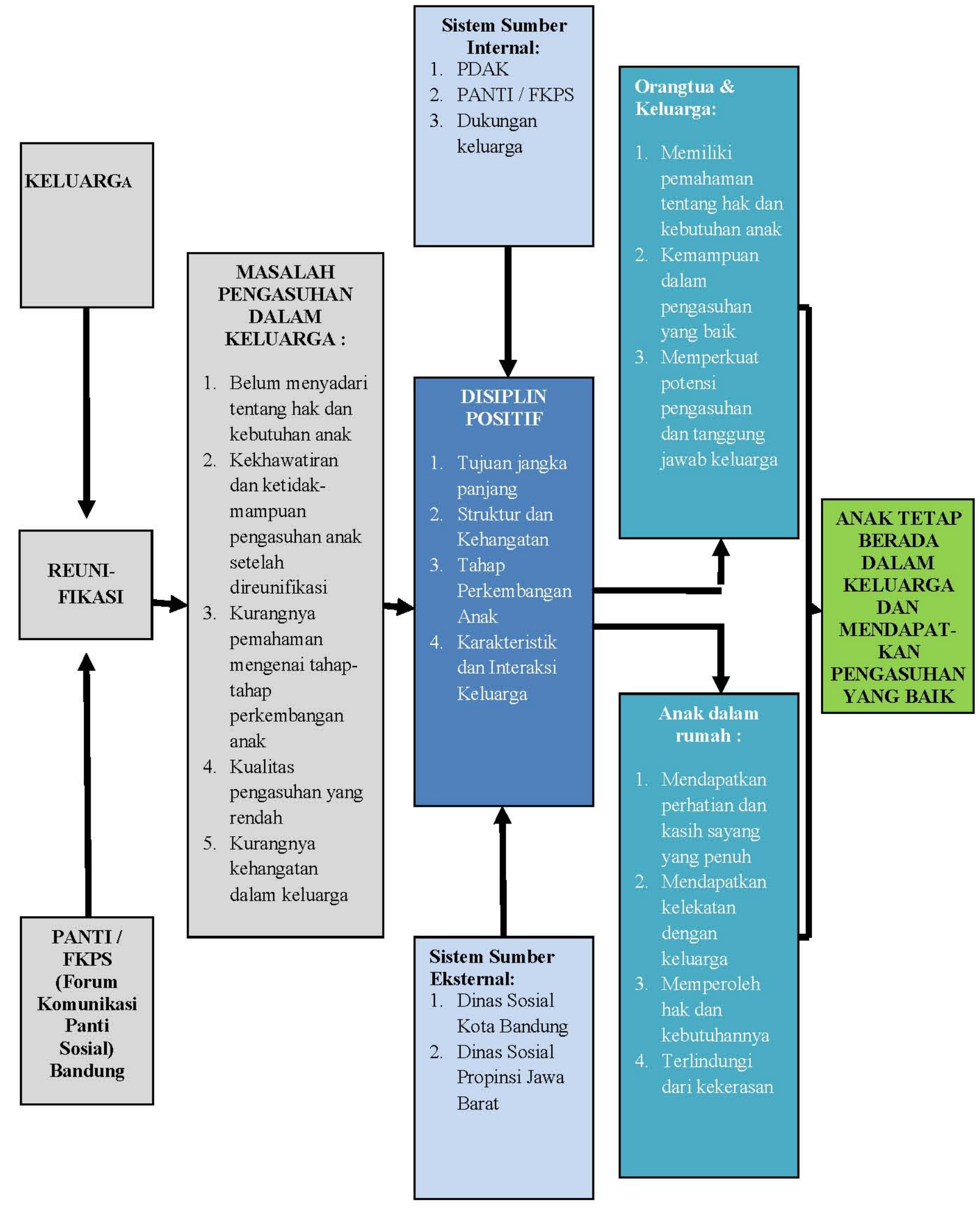

Gambar 3

Penyempurnaan Model Intervensi Penerapan Disiplin Positif 
Penggunaan pendekatan ini didasari pertimbangan bahwa ciri-ciri dan karakteristik keluarga yang telah direunifikasi lebih menggambarkan kepada situasi rendah dan kurang berdayanya keluarga dalam hal pengasuhan. Hal ini dapat terlihat dimana orangtua dan keluarga lebih memilih panti menjadi solusi utama. Sementara itu, pada dasarnya keluarga tersebut memiliki keinginan yang kuat untuk mengasuh dan membesarkan anak-anak. Keterpisahan yang terjadi bertahun-tahun membuat anak dan keluarga membutuhkan kembali waktu untuk saling beradaptasi. Tidak tersedianya kehangatan, informasi dan arahan yang jelas dalam pengasuhan keluarga, dapat mendorong anak yang telah direunifikasi kembali lagi ke dalam panti.

Hasil asesmen diketahui bahwa orangtua dan keluarga memiliki keinginan dan kemauan yang kuat untuk dapat bersatu kembali dengan anak-anak mereka serta dapat memberikan perhatian dan kasih sayang kepada anak. Di sisi lain, orangtua dan keluarga juga memiliki kekhawatiran mengenai mampu atau tidak mereka memberikan pengasuhan seperti yang telah anak-anak mereka dapatkan di dalam panti.

Keluarga merupakan tempat terbaik bagi tumbuh kembang anak. Orangtua dan keluarga memiliki niat dan keinginan untuk dapat tetap mengasuh dan tinggal bersama anggota keluarga. Hal ini merupakan modal untuk pelaksanaan intervensi penerapan disiplin positif bagi orangtua dan keluarga. Model intervensi yang telah dilaksanakan tersebut digambarkan dalam bagan berikut ini (gambar 4).

Berdasarkan temuan dalam penelitian ini sebagaimana terdapat dalam bagan gambar 4 dibawah ini, maka model ini dapat diimplementasikan dalam kegiatan penerapan disiplin positif dan good parenting training. Upaya untuk memperkuat pengasuhan orangtua oleh keluarga kepada anak yang direunifikasi dilakukan melalui penerapan disiplin positif dan pelatihan pengasuhan. Disiplin positif adalah proses pengasuhan yang menyediakan prinsip dasar bagi pengasuhan dalam keluarga yang berfokus kepada prinsip penghargaan, disiplin tanpa kekerasan, berfokus kepada solusi dan memperhatikan tahap perkembangan anak.

Tujuan yang diinginkan dari intervensi yang dilaksanakan, yaitu:

1. Tujuan Umum:

Memberikan atau menyampaikan informasi dan konsep yang berupa pengetahuan dan keterampilan praktis untuk memperkuat pengasuhan dalam keluarga.

2. Tujuan Khusus:

a. Meningkatnya pengetahuan dan pemahaman orangtua dan keluarga mengenai hak dan kebutuhan anak dalam keluarga.

b. Meningkatkan kesadaran dan kemampuan orangtua dan keluarga mengenai pengasuhan anak yang permanen dalam keluarga.

c. Memperkuat potensi pengasuhan dan tanggung jawab keluarga dalam pengasuhan.

d. Menyediakan dan memberikan perhatian dan kasih sayang kepada anak dalam pengasuhan keluarga.

e. Memperoleh dukungan dari kelompok orangtua dalam meningkatkan pengasuhan anak dalam keluarga. 


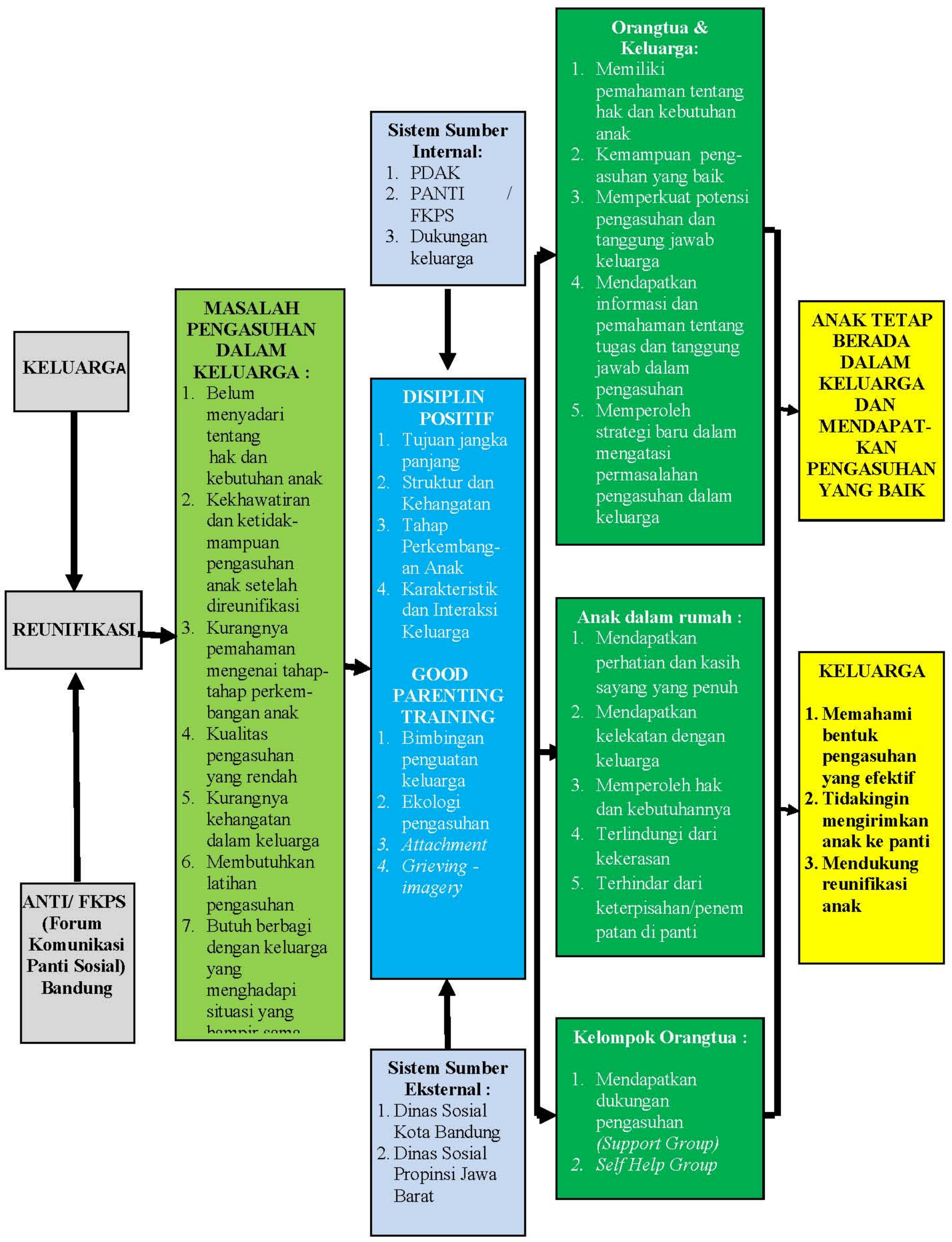

Gambar 4

Pelaksanaan Model Intervensi Penerapan Disiplin Positif Anak 
Beberapa hal yang menjadi evaluasi serta perhatian khusus pelaksanaan intervensi dalam penelitian yang dilaksanakan adalah :

1. Pada penentuan tujuan jangka panjang pengasuhan, orangtua dan keluarga perlu dilibatkan serta tetap diberikan kesempatan untuk menyampaikan gambaran yang mereka pahami. Hal tersebut bertujuan untuk membantu orangtua dan keluarga mengenali cara pengasuhan yang selama ini mereka terapkan di dalam keluarga. Pada kegiatan ini juga, pemberian contoh-contoh kasus serta pembahasan situasi yang mereka hadapi sehari-hari merupakan salah satu cara yang dipandang efektif untuk membantu mereka mengidentifikasi tujuan jangka panjang pengasuhan.

2. Pada penyediaan informasi dan kehangatan dalam keluarga, hasil penggalian kebiasaan dan nilai-nilai dalam keluarga tidak dapat digeneralisasikan. Hal ini juga dipengaruhi berbagai faktor seperti latar belakang pendidikan, budaya dan sistem nilai yang dianut dalam keluarga. Instrumen yang dipakai perlu disederhanakan ke dalam bahasa sehari-hari yang dipahami oleh orangtua dan keluarga berdasarkan tingkat pendidikan dan budaya keluarga.

3. Pemberian pelatihan pengasuhan atau good parenting training, salah satu teknik yang dapat membantu orangtua dan keluarga memahami pengasuhan secara umum. Penggunaan kelompok merupakan salah satu strategi yang dapat membantu sosialisasi serta keterbukaan orangtua dan keluarga. Berkaitan dengan materi pelatihan perlu disesuaikan dengan tingkat pemahaman orangtua dan keluarga juga akan lebih tepat dan optimal jika menggunakan bahasa ibu yang digunakan sehari-hari oleh orangtua dan keluarga. Perlunya memberikan kesempatan bagi orangtua dan keluarga untuk memahas kasus pengasuhan sehari-hari yang mereka hadapi.

4. Rehearshal atau latihan, sangat diperlukan untuk melatih orangtua dan keluarga dalam menerapkan perilaku pengasuhan baru berkaitan dengan disiplin positif. Dengan menyediakan berbagai pilihan topik yang akan diperankan akan sangat membantu serta memperkaya orangtua dan keluarga. Setting tempat juga mempengaruhi suasana latihan menjadi lebih hidup. Penggunaan kelompok dalam pelatihan sebagai media juga perlu dikondisikan dengan baik.

5. Media untuk share bagi orangtua dan keluarga seperti support group orangtua setelah mengikut pelatihan pengasuhan juga perlu diperkuat. Dengan demikian, penggunaan kelompok ini dapat menjadi self help group bagi para orangtua dan keluarga yang telah direunifikasi dan meiliki karakteristik yang sama.

\section{Simpulan}

Fenomena penempatan anak di panti menjadi salah satu solusi utama yang dijadikan oleh orangtua dan keluarga dalam mengatasi permasalahan keluarga, khususnya dalam permasalahan ekonomi dan pendidikan tanpa mempertimbangkan bahwa itu menimbulkan dampak yang buruk terhadap perkembangan anak. Peran dan fungsi pengasuhan keluarga menjadi beralih kepada pihak lain dalam hal ini panti asuhan, yang mendasar adalah dari sisi pengasuhan penempatan anak di dalam panti asuhan sama sekali tidak menghasilkan pengasuhan yang baik dan berdampak buruk terhadap perkembangan anak. Oleh karena itu dalam rentang pengasuhan, panti tetap merupakan alternatif terakhir, sehingga ketika banyak anak ditempatkan di panti dan mereka tidak membutuhkan pengasuhan alternatif, anak tetap harus berada atau dikembalikan kedalam keluarganya.

Kondisi awal bahwa keluarganya juga kurang memiliki pengetahuan tentang pengasuhan, mereka juga berada dalam karakteristik yang terbatas, menjadi faktor pendukung dalam penempatan anak di dalam panti. Ketika anak direunifikasi dan agar anak tetap terjaga pengembaliannya juga agar ada peningkatan dalam pengasuhannya maka dibutuhkan upaya penguatan terhadap pengasuhannya. 
Pada posisi inilah disiplin positif dan good parenting memperoleh peluang untuk diterapkan. Maka dalam kapasitas seperti inilah penelitian ini dilakukan, dan ternyata hasilnya adalah pendekatan ini dapat dapat memberikan pengaruh pada perubahan pemahaman orangtua mengenai hak dan kebutuhan anak, meningkatkan kesadaran diri para orangtua dan keluarga, meningkatkan pengetahuan dan keterampilannya serta meningkatkan motivasi dan komitmen orangtua dan keluarga dalam pengasuhan dan penempatan anak di dalam keluarga serta orangtua dapat melaksanakan fungsi dan perannya kembali secara utuh.

Kesimpulan lain yang diperoleh dari model intervensi penerapan disiplin positif dalam upaya penguatan pengasuhan keluarga adalah yang didapat melalui proses penelitian secara keseluruhan mengenai langkah-langkah intervensi mulai dari persiapan sosial sampai dengan evaluasi yang tidak selalu bisa dilakukan dalam bentuk linear. Perbaikan dan penyempurnaan model sejak kegiatan penelitian sampai dengan penelitian menunjukkan bahwa untuk merancang model intervensi yang tepat dan efektif diperlukan siklus yang lebih memungkinkan peneliti atau pekerja sosial mengulang tahap-tahap tertentu. Hal ini diperlukan karena model intervensi yang sudah dirancang mungkin saja tidak bisa memecahkan masalah-masalah mendasar yang belum teridentifikasi atau kegiatan yang dilakukan belum menjawab kebutuhan yang sesungguhnya dari orangtua dan keluarga.

Hasil penelitian menunjukkan adanya penambahan pengetahuan orangtua dan keluarga yang telah direunifikasi mengenai kebutuhan, hak dan cara pengasuhan anak. Pengetahuan dan pemahaman tersebut berdampak kepada perubahan pada pola pengasuhan dan sikap orangtua dan keluarga terhadap anak. Penelitian ini juga menghasilkan implikasi praktis berupa Model Penerapan Disiplin Positif dalam Pengasuhan oleh Keluarga yang Telah Direunifikasi. Secara teoritik, penelitian juga mengkonfirmasi beberapa asumsi tentang pendekatan disiplin positif khususnya tentang peran pemberian kehangatan dalam pengasuhan, serta asumsi tentang tahapan perkembangan anak dari Erick Erickson yang sangat perlu dipahami oleh orang tua agar dapat memberikan pengasuhan sesuai kebutuhan perkembangan anak.

\section{Rekomendasi}

Berdasarkan hasil penelitian dapat diketahui bahwa pelaksanaan model penerapan disiplin positif dalam memperkuat pengasuhan anak di dalam keluarga dapat dilaksanakan dengan baik. Sedangkan evaluasi yang dilakukan, diketahui bahwa kemajuan dan perubahan yang dicapai orangtua dan keluarga setelah pelaksanaan intervensi relatif masih terbatas. Oleh karena itu, rekomendasi yang diberikan adalah bahwa model intervensi ini masih perlu diujicoba dalam upaya memperkuat pengasuhan keluarga yang telah direunifikasi. Pengujian efektifitas dan ketepatan model intervensi ini memiliki prasyarat, seperti dilakukan kepada orangtua dan keluarga yang memiliki ciri-ciri dan karakteristik yang sama dengan informan dalam penelitian yang dilakukan. Akan tetapi tidak tertutup kemungkinan bahwa model intervensi ini dapat diujicobakan kepada orangtua dan keluarga yang tidak memiliki karakteristik tidak persis sama dengan populasi penelitian. Untuk mendukung stabilitas dan keberlanjutan model, maka peneliti mengharapkan adanya dukungan dan perhatian dari berbagai pihak. Adapun rekomendasi yang yang perlu disampaikan peneliti adalah :

\section{Rekomendasi bagi penelitian lanjutan}

Kepada praktisi dan perguruan tinggi yang memiliki ketertarikan untuk melakukan penelitian dengan tema dan tempat yang sama, maka peneliti merekomendasikan untuk melakukan penelitian lanjutan mengenai bagaimana penelitian berikutnya secara detail mencoba menguraikan pendekatan disiplin positif ke dalam instrumen yang sangat sesuai dengan konteks Indonesia. Karena apabila waktunya lebih lama, kita dapat menemukan 
cara bagi orangtua dengan karakteristik yang terbatas secara pengetahuan, ekonominya akan mampu menemukan tujuan jangka panjang pengasuhannya. Akan tetapi karena keterbatasan waktu, peneliti dalam hal ini tidak terlalu banyak mengembangkan teknikteknik tersebut.

Ke depan diharapkan penelitian lanjutan dapat menemukan bagaimana caranya agar para orangtua tersebut berpikir kedepannya mengenai penentuan tujuan jangka panjang pengasuhan mereka, dan bagaimana orangtua mampu mngkreasikan kehangatan atau struktur dalam keluarga dengan berbagai situasi dan sesuai dengan tingkat perkembangan anak.

Penelitian lanjutan berikutnya diharapkan mampu untuk memetakan dan mengembangkan teknik-teknik penerapan disiplin positif dalam konteks Indonesia.

Mengingat pendekatan ini masih tergolong baru di Indonesia, dan karena dilakukan kepada keluarga yang direunifikasi maka perlu untuk mengkomparasikan dari sisi kelembagaan (panti). Dalam posisi anak-anak tersebut akan direunifikasi (transisi) anak tetap berada di dalam panti, sehingga para pengasuh di panti seharusnya juga perlu mempelajari dan mengaplikasikan disiplin positif dan good parenting ini. Hal ini sangat penting dalam melanjutkan proses keberlanjutan pengasuhan baik untuk anak yang berada dalam masa transisi akan kembali kepada keluarga atau bagi anak yang tinggal di panti yang memang benar-benar membutuhkan pengasuhan alternatif sekalipun sifatnya untuk sementara.

Pada penelitian berikutnya, perlu untuk memikirkan bagaimana disiplin positif itu juga diaplikasikan dalam keluarga-keluarga yang secara khusus memiliki isu perlindungan, dan tidak semata-mata dari isu pendidikan atapun ekonominya. Dan ini akan menjadi salah satu isu yang sangat kompleks. Pada penelitian lanjutan diharapkan dapat menemukan model yang tepat untuk keluarga yang memiliki isu perlindungan seperti ini.

\section{Rekomendasi bagi Akademisi}

Untuk pengembangan pendidikan pekerja sosial khususnya bidang kajian anak dengan keluarga, diharapkan ada pengkajian khusus tentang penerapan pendekatan disiplin positif ini secara mendasar, sehingga ini menjadi salah satu bagian yang sangat menarik jika dapat dimasukkan dalam topik pembelajaran mahasiswa untuk bisa menjadikan perubahan sistem pengasuhan berbasis keluarga itu berarah kepada semua unsur.

\section{Rekomendasi bagi Orangtua dan Keluarga}

Adapun dasar pemikiran dari rekomendasi yang ditujukan kepada orangtua dan keluarga ini adalah mengingat bahwa apa yang telah dicapai dalam program intervensi belum sepenuhnya terinternalisasi dalam diri partisipan, sehingga dibutuhkan pengkondisian oleh orangtua dan keluarga itu sendiri untuk mencapai tujuan yang lebih optimal. Keluarga diharapkan dapat menjaga dan meningkatkan lagi apa yang telah dicapai dalam proses intervensi yang telah dilakukan peneliti. Orangtua dan keluarga diharapkan dapat mengembangkan pola asuh yang positif, menyediakan kehangatan dalam keluarga (memiliki waktu untuk berkumpul dan bercanda dalam keluarga), informasi serta aturan yang jelas bagi setiap perilaku anggota keluarga dan memahami tahap-tahap perkembangan anak. Sehingga penempatan anak di dalam panti dapat dihindari atau diminimalisasi.

\section{Rekomendasi bagi Pusat Dukungan Anak dan Keluarga (PDAK)}

Karena ini merupakan tindak lanjut program dari Pusat Dukungan Anak dan Keluarga, maka untuk keberlanjutan atau sustainbilitinya adalah bagaimana PDAK bisa mengembangkan sistem penerapan janji hati atau komitmen orangtua dalam pengasuhan anak dalam keluarga sebagai sebuah proses 
yang berkesinambungan. Pusat Dukungan Anak dan Keluarga diharapkan dapat menjadikan kelompok orangtua atau keluarga yang telah mengikuti good parenting training, sebagai media bagi keluarga atau self help group dan support group dalam mendapatkan dukungan serta penguatan pengasuhan berbasis keluarga. Pembentukan support group ini diharapkan dapat disesuaikan berdasarkan latar belakang pendidikan orangtua dan keluarga, latar belakang ekonomi serta letak wilayah/ tempat inggal orangtua dan keluarga. Perlunya menindak lanjuti setiap kerjasama yang telah disepakati para penyedia layanan bagi anak dan keluarga. Hal ini dibutuhkan untuk menjamin keberlanjutan dari pengasuhan anak berbasis keluarga khususnya di Kota Bandung, yang dapat mendukung para orangtua dan keluarga dari segi pemberdayaan ekonomi keluarga.

\section{Daftar Pustaka}

Allie C. Kilpatrick, Tomas P. Holland. 2003. Working With Families: An Integrative Model by Level of Need. Pearson Education. Inc.

Dubois. Howard, Diane De Panfilis. 2000. Handbook for Child Protection Practice. United States: Sage Publications, Inc.

Hennie Boeije. 2010. Analysis in Qualitative Research. SAGE Publications Ltd.

Jacqueline Corcoran. 2000. Evidence-Based Social Work Practice with Family, A lifespan Approach. Springger Publishing Company. Inc.

J.B. Brooks. 2001. Parenting. Mayfield Publish Company

Jean McNiff with Jack Whitehead. 2002. Action Research: Principles and Practice, Second Edition. London: Routledge Falmer 11 New Fetter Lane

Joan E.Durrant, Ph.D. 2007. Positive Discilpine, What It Is and How to Do It. Keen Media (Thailand) Co.Ltd.

Juke R. Siregar. 2004. Kebutuhan dan Peran Ibu dalam Pengasuhan Anak. Jakarta

J.Zevalkink. 1997. Attachment in Indonesia. Netherlands: University of Nijmegen

Kate Wilson \& Adrian James. 2004. The Child Protection Hand Book, Second Edition. United Kingdom: Bailliere Tindull

Khairuddin. 2002. Sosiologi Keluarga. Yogyakarta: Liberty

Marlene G. Cooper \& Joan Granucci Lesser. 2005. Clinical Social Work Practice an Integrated Approach 